\title{
Trace Metal Determination in the Medicinal Plant Hyoscyamus (Solanaceae) by Inductively Coupled Plasma Optical Emission Spectrometry
}

\author{
Cumali Keskin ${ }^{a *}$, Erdener Kisin $^{\mathrm{b}}$, and Murat Yavuz ${ }^{\mathrm{b}^{*}}$ \\ a Department of Nutrition and Dietetics, School of Health, Mardin Artuklu University, 47100 Mardin, Turkey \\ b Department of Chemistry, Faculty of Science, Dicle University, 21280 Diyarbak1r, Turkey
}

\section{INTRODUCTION}

The term "herbal medicine" is defined as a plant-derived material or preparation with therapeutic or other human health benefits, which contains either raw or processed ingredients from one or more plants. Included are also medical and aromatic compounds that have become of special interest as a complementary choice to conventional medicine due to their efficiency in the treatment of diseases such as gastric ulcers, asthma, and Parkinson's disease $(1,2)$. The majority of herbal drugs are extracted, purified, and characterized from plants. Thus, it could easily be concluded that herbal plants are a successfull strategy as an alternative to synthetic chemical procedures. Additionally, it could eliminate the use of toxic chemicals, lowering the production cost and sustainability. Plants and their different extracts can be consumed either as a liquid or solid. In 2005, the World Health Organization (WHO) highlighted the increasing use of herbal medicinal plants as complementary and an alternative to medicine (CAM) in many developed and developing countries (3). Many countries such as Europe and North America approved the use of some herbal plants and their extracts as a product containing vitamins, minerals, amino acids, herbs, or other

\footnotetext{
*Corresponding autbors

Cumali Keskin

E-mail: ckeskinoo@gmail.com

Tel: 0090 (482) 2134002-7203

Fax: 0090 (482) 2134004

and

Murat Yavuz

E-mail: myavuz@dicle.edu.tr

Tel: 0090 (412) 2488550-3054

Fax: 0090 (412) 2488300
}

\begin{abstract}
The concentrations of $\mathrm{Cd}, \mathrm{Ni}$, $\mathrm{Cu}, \mathrm{Pb}, \mathrm{Cr}, \mathrm{Fe}, \mathrm{B}$, and $\mathrm{Al}$ were determined in four different medicinal plants of the Hyoscyamus species: Hyoscyamus reticulatus L., Hyoscyamus leptocalyx STAPF, Hyoscyamus aureus L., and Hyoscyamus albus $L$. by ICP-OES. By considering the sensitivity of ICP-OES with respect to the trace level determination of $\mathrm{Cd}, \mathrm{Ni}, \mathrm{Cu}, \mathrm{Pb}$, $\mathrm{Cr}, \mathrm{Fe}, \mathrm{B}$, and $\mathrm{Al}$ in the studied plant samples and the limitations of sample amount possible in a microwave digestion procedure, the ashing method was applied before analysis and proved the quantitative measurements of the elements.

The accuracy of the method was verified by comparison to the certified reference sample NCSZC 73014 Tea Leaves. The RSD values were between $0.14-10.4 \%$, while the error values were in the $90-107 \%$ range. The results show that with the proposed method higher concentrations of $\mathrm{Ni}, \mathrm{Cr}, \mathrm{Pb}, \mathrm{Fe}$, and $\mathrm{B}$ were determined in $\mathrm{H}$. aureus Interestingly, the concentration of $\mathrm{Cu}$ in $\mathrm{H}$. reticulatus was approximately 48.5 times higher than the mean $\mathrm{Cu}$ values of the other three Hyoscyamus species, while the $\mathrm{Pb}$ concentration levels in $H$. aureus were 17.8 times higher than in the $H$. reticulatus $L$., $H$. leptocalyx STAPF, and $H$. albus $L$. species.
\end{abstract}

botanical concentrates according to regulatory agencies such as FAO (Food and Agriculture Organization) / WHO (4-6).

The Hyoscyamus species are known as rich sources of pharma- ceutically valuable tropane alkaloids, which have the 8-azabicyclo [3.2.1] octane structure in common due to structure activity relationship (7-9). It has been reported that the Hyoscyamus species of Anatolia have a high alkaloid content which could cause poisoning in children due to improper use (10). The incidence of plant poisoning in Turkey is about $6 \%$ (10). Among these are tropane alkaloids such as Hyoscyamine (also known as daturine), scopolamine, and atropine which can cause pharmacological and toxic effects such as reduced muscle spasms in the digestive or urinary tract, and reduced fluid secretions from certain glands or organs (11). Tropane alkaloids are known to be competitive antagonistic chemicals of the muscarinic acetylcholine receptor and are classified as anticholinergic agents $(8,12)$. However, they can be used in the treatment of motion sickness and as an analgesic before an operation (13). Psychoactive properties using Hyoscyamus niger include hallucinations and a sensation of flight (14). The effects of these alkaloids contribute to stimulation and depression of the central nervous system (15). Antioxidative, anti-inflammatory, antipyretic, antihyperuricemis, and xantine ozidase inibitory effects of the Hyoscyamus species have also been reported (16-19). In addition to tropane alkaloids, seven non-tropane alkaloids (Calystegin A3, Calystegin B1, Calystegin B2, deoxynojirimycin, Australine, Swainsonine, Castanospermine) known as calystegins were also determined in the Hyocyamus species (20).

Herbal plants are known to have in general been originated in 
ancient times in Africa, the Asian subcontinent, and in North, Central, and South America (21). In 1996, FAO reported that Turkey has a rich diversity of plants which include 163 families, 1,225 genera, and 9,000 species $(22,23)$. According to recent studies, Turkey has approximately12,000 plant taxa, of which nearly 3000 are endemic (24). The majority of studies focus on the use of endemic species as medicinal plants. However, the quality of medicinal plants depends on their chemical con-stituents. Sustainability of medicinal plant production is dependent on the quality of the product. Heavy metals, especially toxic ones, limit the use of medicinal plants. It is known that heavy metals accumulate in plants through their root system and show their distribution in the root, leaf, and fruit. Thus, herbal plants could also be employed as biomonitors. According to our literature survey, reports on endemic Hyoscyamus species in the southeastern region of Anatolia, Turkey, are limited. In this study, we investigated four endemic Hyoscyamus species (Hyoscyamus reticulatus $L$., Hyoscyamus leptocalyx STAPF, Hyoscyamus aureus $L$., and Hyoscyamus albus $L$.) which were collected from local sources and their $\mathrm{Cd}, \mathrm{Ni}, \mathrm{Cu}, \mathrm{Pb}, \mathrm{Cr}, \mathrm{Fe}, \mathrm{B}$, and Al concentrations determined by inductively coupled plasma optical emission spectrometry (ICP-OES).

The elements were selected due to their bioavailability in the studied plants and due to toxicity of some. By considering the possible antimicrobial, antifungal, etc., effects of the volatile oils contained in these plants, the metal concentrations in the hexane and methanole fractions were also determined.

\section{EXPERIMENTAL}

\section{Instrumentation}

Concentrations of $\mathrm{Cd}, \mathrm{Ni}, \mathrm{Cu}, \mathrm{Pb}$, $\mathrm{Cr}, \mathrm{Fe}, \mathrm{B}$, and $\mathrm{Al}$ were determined by using a PerkinElmer ${ }^{\circledR}$ Optima ${ }^{\mathrm{TM}}$ 2100 DV ICP-OES (PerkinElmer, Inc., Shelton, CT, USA). The wavelengths of the elements and the instrumental operating conditions $(25,26)$ are listed in Table I.

\section{Standard Solutions and Reagents}

The stock solutions of $\mathrm{Cd}, \mathrm{Ni}$, $\mathrm{Cu}, \mathrm{Pb}, \mathrm{Cr}, \mathrm{Fe}, \mathrm{B}$, and $\mathrm{Al}$ were prepared from their individual standard solutions at $1000 \mu \mathrm{g} \mathrm{mL} \mathrm{mL}^{-1}$ (High Purity Standards, Charleston, SC, USA). Required dilutions were performed for lower concentrations. During the study, all chemicals used were of high purity reagent grade unless otherwise stated. Doubly distilled water was used for all experimental studies using a Milli${ }^{\circledR}$ purification system (Millipore Corporation, USA). All glass materials were cleaned with $1.0 \mathrm{~mol} \mathrm{~L}^{-1}$ of $\mathrm{HNO}_{3}$ and kept permanently full of
$1.0 \mathrm{~mol} \mathrm{~L}^{-1}$ of nitric acid when not in use. $\mathrm{HNO}_{3}(65 \%), \mathrm{H}_{2} \mathrm{O}_{2}(35 \%)$, and $\mathrm{HCl}(36.5-38.0 \%)$ were obtained from Sigma Aldrich, Germany.

Certified reference material (CRM) NCS ZC 73014 Tea Leaves was obtained from the China National Analysis Center for Iron and Steel (Bejing, P.R. China) and used to check the accuracy of the results.

\section{Collection of Plant Samples}

Hyoscyamus species were collected at the flowering stage from different locations in the vicinity of Mardin in 2012 by Dr. Cumali Keskin (co-author). Voucher specimens were deposited at the Dicle University Herbarium, Department of Biology, Faculty of Science, Diyarbakır, Turkey. Taxonomic identification of the plant materials

TABLE I

Insstrumental Operating Conditions for ICP-OES

\begin{tabular}{ll}
\hline Parameters & \\
\hline RF power & $1450 \mathrm{~W}$ \\
Plasma gas flow rate & $15 \mathrm{~L} / \mathrm{min}$ \\
Auxiliary gas flow rate & $0.2 \mathrm{~L} / \mathrm{min}$ \\
Nebulizer gas flow rate & $0.8 \mathrm{~L} / \mathrm{min}$ \\
Sample flow rate & $1.5 \mathrm{~L} / \mathrm{min}$ \\
View mode & Axial-Radial \\
Read & Peak area \\
Source equilibration time & $15 \mathrm{~s}$ \\
Read delay & $60 \mathrm{~s}$ \\
Replicates & 3 \\
Background correction & $2-$ point (manual point correction) \\
Spray chamber & Scott-type spray chamber \\
Nebulizer & Cross-Flow GemTip ${ }^{\mathrm{TM}}$ Nebulizer \\
& (HF resistant) \\
Detector & CCD (charge-coupled device) \\
Purge gas & Nitrogen \\
Shear gas & Air \\
Gas & Argon \\
Analytical wavelengths & Cd 228.804 nm, Ni 231.604 nm, \\
& Cu 327.393 nm, Cr $267.716 \mathrm{~nm}$, \\
& B 249.772 nm, Al 396.153 nm \\
\hline
\end{tabular}


was confirmed by Dr. A. Selçuk Ertekin from the same institution. For experimental studies, the materials were individually stored in polyethylene bags, and brought to the laboratory for preparation and treatment.

\section{Preparation and Digestion of Plant Species}

The plants were first washed under freshly running tap water, followed with distilled water to avoid possible heavy metal contamination from tap water and to eliminate any foreign substances such as soil, bugs, and thoroughly rinsed again with deionized water. Then the samples were cleaned twice with distilled water, finally dried at room temperature for 48 hours, and stored in polyethylene containers.

It is well known that digestion with strong acids and their mixtures does not give quantitative results for heavy metals. On the other hand, sample amount is a disadvantage with a microwave method. Above $0.25 \mathrm{~g}$ of sample, excess gas pressure in Teflon ${ }^{\circledR}$ vessels causes problems. However, considering the low level concentrations of heavy metals present in the studied plants, sample amount is a limitation in the microwave method. By considering the sensitivity of ICP-OES and the abovementioned limitations, the ashing method was selected for digestion of the plants.

Before digestion, the samples were dried again in an oven at $75^{\circ} \mathrm{C}$ for 48 hours and then ground in a porcelain mortar to obtain a fine powder. Approximately, $3.0 \mathrm{~g}$ of the powdered samples was placed into porcelain crucibles and left standing in an ash oven for one day at $100{ }^{\circ} \mathrm{C}$. The samples were then ashed at $525{ }^{\circ} \mathrm{C}$ for 5 hours, $3.0 \mathrm{~mL}$ of concentrated nitric acid was added, and the mixture heated on a heater for 2 hours at $525^{\circ} \mathrm{C}$ until dryness was achieved. Finally, $3.0 \mathrm{~mL}$ of $\mathrm{HNO}_{3}$ and $\mathrm{HCl}(3: 1, \mathrm{v} / \mathrm{v})$ was added to the crucibles and heated to dryness. Then, $10.0 \mathrm{~mL}$ of $1.0 \mathrm{M}$ of $\mathrm{HNO}_{3}$ was added to the samples, transferred to the PTFE tubes, and analyzed by ICP-OES.

Certified reference material NCS ZC 73014 Tea Leaves was also digested using same procedure as described above to check the accuracy of the method.

\section{RESULTS AND DISCUSSION}

\section{Analytical Characteristics}

Stock standard solutions of $\mathrm{Cd}$, $\mathrm{Ni}, \mathrm{Cu}, \mathrm{Pb}, \mathrm{Cr}, \mathrm{Fe}, \mathrm{B}$, and $\mathrm{Al}$ were diluted with $1.0 \mathrm{~mol} \mathrm{~L}^{-1}$ of nitric acid to the desired concentration values. The intensities of the diluted metal solutions at the concentration range of 50-2000 $\mathrm{ng} \mathrm{mL}^{-1}$ were measured by ICP-OES. Linear calibration equations were obtained by plotting the concentration values versus the related intensities for each of the elements. The analytical characteristics of the ICP-OES method listed in Table II were evaluated by considering the linear range, slope, intercept, and correlation coefficient of the linear plot, limit of detection (LOD), limit of quantification (LOQ), and relative standard deviation (RSD). Three times the standard deviation of the

\section{TABLE II}

Analytical Characteristics of ICP-OES

\begin{tabular}{|c|c|c|c|}
\hline $\begin{array}{l}\text { Ele- } \\
\text { ment }\end{array}$ & $\begin{array}{l}\text { Linear } \\
\text { Range } \\
\left(\mu \mathrm{g} \mathrm{mL} \mathrm{mL}^{-1}\right)\end{array}$ & $\begin{array}{l}\text { LOD } \\
\text { (ng }\end{array}$ & $\begin{array}{l}\text { LOQ } \\
\left.\mathrm{L}^{-1}\right)\end{array}$ \\
\hline $\mathrm{Cd}$ & $0.05-1.5$ & 3.3 & 11 \\
\hline $\mathrm{Ni}$ & $0.05-1.5$ & 5.1 & 17 \\
\hline $\mathrm{Cu}$ & $0.05-1.5$ & 2.8 & 9.2 \\
\hline $\mathrm{Cr}$ & $0.05-1.5$ & 4.3 & 14 \\
\hline $\mathrm{Pb}$ & $0.05-1.5$ & 9.0 & 30 \\
\hline $\mathrm{Fe}$ & $0.05-1.5$ & 4.2 & 14 \\
\hline B & $0.05-1.5$ & 12.0 & 40 \\
\hline $\mathrm{Al}$ & $0.05-1.5$ & 3.2 & 11 \\
\hline
\end{tabular}

slope ratio was employed to calculate the LOD, while 10 times the ratio was accepted as the LOQ. The $\%$ RSD was calculated from the ratio of the standard deviation to the mean signal.

The accuracy of the ICP-OES method was verified by analyzing certified reference material NCSZC 73014 Tea Leaves and Table III lists the certified and found values which compared well with each other. However, the certified value for $\mathrm{Al}$ is not included because it is not provided for this CRM.

The detailed statistical approaches were considered and show the applicability of the ashing method before ICP-OES measurement of the elements. The standard deviation (SD), relative standard deviation (RSD), and the error percentages are also listed in Table III. By considering the SD and RSD values, it can be said that the method has high precision levels. The RSD values were found lower than 5\% for $\mathrm{Ni}, \mathrm{Cu}, \mathrm{Pb}, \mathrm{Cr}, \mathrm{B}$, and $\mathrm{Al}$, and $10.4 \%$ for $\mathrm{Fe}$ and $\mathrm{Cd}$. The accuracy of the method as well as all other important analytical parameters were also considered by evaluating the error percentages which were in the $90-107 \%$ range. Thus, these high precision and accuracy values show the applicability of this method for the analysis of real plant samples.

\section{Distribution of $\mathrm{Cd}, \mathrm{Ni}, \mathrm{Cu}$, $\mathrm{Pb}, \mathrm{Cr}, \mathrm{Fe}, \mathrm{B}$, and $\mathrm{Al}$ in the Hyoscyamus (Solanaceae) Species of Herbal Plants}

The ashing method was applied to the analysis of the Hyoscyamus species and was validated through the analysis of the certified reference material NCS ZC 73014 Tea Leaves for the determination of $\mathrm{Cd}$, $\mathrm{Ni}, \mathrm{Cu}, \mathrm{Pb}, \mathrm{Cr}, \mathrm{Fe}, \mathrm{B}$, and $\mathrm{Al}$. For this purpose, four different Hyoscyamus species (Hyoscyamus reticulatus L., Hyoscyamus leptocalyx STAPF, Hyoscyamus aureus 
L., and Hyoscyamus albus L.) were sampled, powdered, and ashed for the determination of their metal concentrations by ICP-OES. The concentrations of the metal ions are listed in Table IV. All of the analyses were performed in triplicate. The SD and RSD values are included in this table to evaluate the precision of the results. As shown, the RSD values were found to be below $10 \%$. Considering the favorable results, further experiments were not performed.

\section{$\mathrm{Cd}$ and $\mathrm{Pb}$ Concentrations}

All of the elements of interest were found at concentration levels that could be determined by ICPOES after the ashing method, except for cadmium (Cd). The con- centrations of Cd were found to be lower than the LOQ in $H$. reticulatus. The highest concentration of Cd was found in $H$. albus at 0.87 $\mathrm{mg} / \mathrm{kg}$, whereas the lowest value was determined in $H$. leptocalyx at $0.14 \mathrm{mg} / \mathrm{kg}$. The provisionally tolerable weekly intake value for lead $(\mathrm{Pb})$ and cadmium $(\mathrm{Cd})$ reported by FAO/WHO is $7 \mu \mathrm{g} / \mathrm{kg} /$ week (27). Thus, the $\mathrm{Pb}$ levels found in the Hyoscyamus species are below WHO limits. The Cd concentrations in medicinal plants are reported to range from 0.731 to $1.121 \mathrm{mg} / \mathrm{kg}$ dry plant material with an average value of $0.878 \mathrm{mg} / \mathrm{kg}$ (28). Thus, the Cd concentrations found in the samples studied are lower than the mean permissable values reported in the literature.

\section{Ni Concentrations}

It is reported that plants require nickel (Ni) at lower $(0.01-5.0 \mathrm{mg} / \mathrm{kg}$ dry weight) concentrations, while at higher concentrations they may cause toxic effects to plants (29). In addition, Ni has been known to play an important role in the production of insulin (30). Ni amounts in medicinal plants from the Negev Desert of Israel are in the concentration range of $0.5-19.3 \mathrm{mg} / \mathrm{kg}$ on dry weight (29). In this study, the $\mathrm{Ni}$ concentrations in the Hyoscyamus species were measured in the 1.9-14.0 $\mu \mathrm{g} \mathrm{g}^{-1}$ range. The permissible limit set by FAO/WHO (1984) in plants was reported at $1.63 \mathrm{mg} / \mathrm{kg}$, while no regulated value is available for medicinal plants (30).

TABLE III

Accuracy of Digestion Method for Cd, Ni, Cu, Pb, Cr, Fe, B and Al in CRM NCS ZC 73014 Tea Leaves (n=3)

\begin{tabular}{lcccccccc}
\hline Parameters & $\begin{array}{c}\mathrm{Cd} \\
\left(\mu \mathrm{g} \mathrm{g}^{-1}\right)\end{array}$ & $\begin{array}{c}\mathrm{Ni} \\
\left(\mu \mathrm{g} \mathrm{g}^{-1}\right)\end{array}$ & $\begin{array}{c}\mathrm{Cu} \\
\left(\mu \mathrm{g} \mathrm{g}^{-1}\right)\end{array}$ & $\begin{array}{c}\mathrm{Pb} \\
\left(\mu \mathrm{g} \mathrm{g}^{-1}\right)\end{array}$ & $\begin{array}{c}\mathrm{Cr} \\
\left(\mu \mathrm{g} \mathrm{g}^{-1}\right)\end{array}$ & $\begin{array}{c}\mathrm{Fe} \\
\left(\mu \mathrm{g} \mathrm{g}^{-1}\right)\end{array}$ & $\begin{array}{c}\mathrm{B} \\
\left(\mu \mathrm{g} \mathrm{g}^{-1}\right)\end{array}$ & $\begin{array}{c}\mathrm{Al} \\
\left(\mu \mathrm{g} \mathrm{g}^{-1}\right)\end{array}$ \\
\hline Certified value & 0.062 & 3.40 & 18.6 & 1.50 & 0.45 & 242 & 14.0 & - \\
Found value & 0.060 & 3.52 & 19.9 & 1.53 & 0.44 & 235.5 & 12.6 & 597.2 \\
$\mathrm{SD}^{\mathrm{a}}$ & 0.005 & 0.152 & 0.028 & 0.007 & 0.014 & 24.6 & 0.155 & 22.7 \\
$\mathrm{RSD}^{\mathrm{b}}(\%)$ & 8.4 & 4.3 & 0.14 & 0.46 & 3.2 & 10.4 & 2.0 & 3.8 \\
Error (\%) & 96.8 & 103 & 107 & 102 & 97.8 & 97.3 & 90.0 & - \\
\hline
\end{tabular}

a Standard deviation.

${ }^{\mathrm{b}}$ Relative standard deviation.

TABLE IV

Distribution of $\mathrm{Cd}, \mathrm{Ni}, \mathrm{Cu}, \mathrm{Pb}, \mathrm{Cr}, \mathrm{Fe}, \mathrm{B}$, and $\mathrm{Al}$ in Hyoscyamus Species (n=3)

\begin{tabular}{lcccccccc}
\hline Plant & $\begin{array}{c}\mathrm{Cd} \\
\left(\mu \mathrm{g} \mathrm{g}^{-1}\right)\end{array}$ & $\begin{array}{c}\mathrm{Ni} \\
\left(\mu \mathrm{g} \mathrm{g}^{-1}\right)\end{array}$ & $\begin{array}{c}\mathrm{Cu} \\
\left(\mu \mathrm{g} \mathrm{g}^{-1}\right)\end{array}$ & $\begin{array}{c}\mathrm{Pb} \\
\left(\mu \mathrm{g} \mathrm{g}^{-1}\right)\end{array}$ & $\begin{array}{c}\mathrm{Cr} \\
\left(\mu \mathrm{g} \mathrm{g}^{-1}\right)\end{array}$ & $\begin{array}{c}\mathrm{Fe} \\
\left(\mu \mathrm{g} \mathrm{g}^{-1}\right)\end{array}$ & $\begin{array}{c}\mathrm{B} \\
\left(\mu \mathrm{g} \mathrm{g}^{-1}\right)\end{array}$ & $\begin{array}{c}\mathrm{Al} \\
\left(\mu \mathrm{g} \mathrm{g}^{-1}\right)\end{array}$ \\
\hline H. reticulatus & $<\mathrm{LOQ}^{\mathrm{a}}$ & $5.4 \pm 0.086$ & $530.2 \pm 7.00$ & $1.27 \pm 0.087$ & $3.50 \pm 0.016$ & $602 \pm 16.1$ & $17.2 \pm 0.59$ & $1147 \pm 62.9$ \\
& $(1.6)^{\mathrm{b}}$ & $(1.3)$ & $(6.9)$ & $(0.4)$ & $(2.7)$ & $(3.4)$ & $(5.5)$ \\
H. leptocalyx & $0.14 \pm 0.0098$ & $1.9 \pm 0.061$ & $5.8 \pm 0.20$ & $0.18 \pm 0.008$ & $1.39 \pm 0.139$ & $268 \pm 19.7$ & $7.8 \pm 0.66$ & $930 \pm 28.4$ \\
& $(7.0)$ & $(3.2)$ & $(3.5)$ & $(4.4)$ & $(10.0)$ & $(7.4)$ & $(8.5)$ & $(3.0)$ \\
H. aureus & $0.26 \pm 0.0042$ & $14.0 \pm 1.101$ & $15.6 \pm 1.34$ & $21.69 \pm 1.172$ & $8.21 \pm 0.439$ & $1278 \pm 117.0$ & $20.7 \pm 1.75$ & $1089 \pm 71.4$ \\
& $(1.6)$ & $(7.9)$ & $(8.6)$ & $(5.4)$ & $(5.4)$ & $(9.2)$ & $(8.5)$ & $(6.6)$ \\
H. albus & $0.87 \pm 0.0558$ & $9.3 \pm 0.353$ & $11.4 \pm 0.50$ & $2.23 \pm 0.098$ & $5.15 \pm 0.349$ & $794 \pm 67.0$ & $20.5 \pm 0.45$ & $1370 \pm 37.3$ \\
& $(6.4)$ & $(3.8)$ & $(4.4)$ & $(4.4)$ & $(6.8)$ & $(8.4)$ & $(2.2)$ & $(2.7)$ \\
\hline
\end{tabular}

${ }^{a}<$ LOQ: Under the limit of quantification. ${ }^{\mathrm{b}}$ The RSD values are given in parentheses. 


\section{Cu Concentrations}

The permissible copper $(\mathrm{Cu})$ concentration in edible plants is $3.0 \mathrm{mg} / \mathrm{kg}$ as regulated by $\mathrm{FAO} /$ WHO. However, there is no regulation available for $\mathrm{Cu}$ levels in medicinal plants (31). Concentrations of $\mathrm{Cu}$ were found at 530.2, 5.8, 15.6, and $11.4 \mathrm{mg} / \mathrm{kg}$, for $H$. reticulatus, $H$. leptocalyx, $H$. aureus, and $H$. albus, respectively. Interestingly, the concentration of $\mathrm{Cu}$ in $H$. reticulatus was found to be approximately 48.5 times higher than the mean $\mathrm{Cu}$ values of the other Hyoscyamus species. The $\mathrm{Cu}$ concentrations in 33 medicinal plants were reported to be in the 1.4-18.1 $\mathrm{mg} / \mathrm{kg}$ range (32). In our study, the results agreed well with the literature values, except for $\mathrm{H}$. reticulatus. Additionally, phytotoxicity was reported when the $\mathrm{Cu}$ concentration was higher than $20 \mathrm{mg} / \mathrm{kg}$ (33). However, no information is available in the literature for comparison of the Cu levels in $H$. reticulatus. Since high Cu concentration levels lead to headache and hypoglycemia, it is recommended not to use $H$. reticulatus for medicinal purposes (33).

\section{Pb Concentrations}

Lead $(\mathrm{Pb})$ is known as one of the most toxic heavy metals and is dangerous to human and animal health. The provisional tolerable weekly intake value for $\mathrm{Pb}$ is reported at $50 \mu \mathrm{g} / \mathrm{kg} /$ week by FAO and WHO (27) and the permissible limit of $\mathrm{Pb}$ in edible plants at $0.43 \mathrm{mg} / \mathrm{kg}$ by FAO/WHO (31). Pb concentrations of some medicinal plants (Baccharis trimera, Maytenus aquifolia, Mikania glomerata, Pfaffia paniculata) sampled from local city markets in Brazil were found in the $3.37-7.03 \mathrm{mg} / \mathrm{kg}$ range (34). In the present study, it was found that the total $\mathrm{Pb}$ concentration in $H$. aureus was 17.8 times higher than the mean value of the other three plants which were $1.27,0.18$, and $2.23 \mathrm{mg} / \mathrm{kg}$, for $H$. reticulatus,
$H$. leptocalyx, and $H$. albus, respectively, indicating that all species were below permissible levels.

\section{Cr Concentrations}

Chromium (Cr) concentrations were determined in the 1.39-8.21 $\mu \mathrm{g} \mathrm{g}^{-1}$ range. The highest concentration of $\mathrm{Cr}$ was found in $H$. aureus, wheras the lowest was determined in $H$. leptocalyx. In another study, the $\mathrm{Cr}$ concentrations were found in the range of $0.56-1.51 \mathrm{mg} / \mathrm{kg}$ in herbal plants collected in the Kisii region, southwest Kenya (31). The concentrations of $\mathrm{Cr}$ in 33 plants obtained from Romanian markets were found to be in the range of $0.1-5.7 \mathrm{mg} / \mathrm{kg}$ (32). In another study, the $\mathrm{Cr}$ concentrations in 16 different parts of medicinal plant samples collected in Lebanon, Syria, Egypt, Italy, and India were found to be in the range of $3.1-55.4 \mathrm{mg} / \mathrm{kg}$ (35). The EU Recommended Daily Allowance (RDA) for chromium(III) of $40 \mu \mathrm{g}$ was set by the Commission Directive 2008/100/EC9, which is equivalent to $12 \mu \mathrm{g}$ chromium per serving (36).

\section{Fe Concentrations}

Iron (Fe) is known as an essential element for humans and animals and $\mathrm{Fe}^{3+}$ is an essential component of hemoglobin. On the other hand, the deficiency of the bioavailable form of iron on the $2+$ oxidation state causes many diseases such as anemia (37). Fe contributes to the oxidation of carbohydrates, proteins, and fats to control body weight (38). Fe concentrations were determined in the $33.2-206.7 \mathrm{mg} / \mathrm{kg}$ range in seven medicinal plants (Artemisia vulgaris, Asparagus adscendens, Cyamopsis tetragonoloba, Galium aparine, Mucuna pruriens, Stevia rebaudiana, Withania somnifera) collected from Peshawar, Pakistan (38). In another study, 33 different types of medicinal plants were obtained from local Romanion mar- kets and their Fe concentrations were determined by FAAS (flame atomic absorption spectrometry) ranging from $23-826 \mathrm{mg} / \mathrm{kg}$ (32). The proton-induced X-ray emission technique was employed to determine trace element concentrations in other samples, including Fe in medicinal plants sampled from Manipur, India, which ranged from 311.1-820.4 mg/kg (39). In our study, the Fe concentrations were determined at 268, 602, 794 and $1278 \mathrm{mg} / \mathrm{kg}$, respectively, for $H$. leptocalyx, $H$. reticulatus, $H$. albus, and $H$. aureus. The reported daily intake of iron in food - the major source of exposure - ranges from 10 to $14 \mathrm{mg}(7,8)$. Drinking water of $0.3 \mathrm{mg} /$ litre would contribute about $0.6 \mathrm{mg}$ Fe to the daily intake. Intake of iron from air is about 25 $\mu \mathrm{g} /$ day in urban areas (40). So, it could be stated that the consumption of the studied plants at high amounts should be avoided due to their high amouns of $\mathrm{Fe}$ and other toxic metals such as $\mathrm{Ni}, \mathrm{Cr}$, and $\mathrm{Pb}$.

\section{B Concentrations}

Boron is known as one of the most essential elements to plants. Boron deficiency in plants could result in reduced growth, yield loss, and even plant death, depending on the severity of deficiency under $1 \mathrm{mg} / \mathrm{kg}$ of boron, while excess of $\mathrm{B}$ is toxic to plants (41). B concentrations were found at 7.8, 17.2, 20.5 , and $20.7 \mathrm{mg} / \mathrm{kg}$ for $H$. leptocalyx, $H$. reticulatus, $H$. albus, and $H$. aureus, respectively. In $H$. aureus, the Fe and B concentrations were also found to be higher than the mean values of the other species. A permissible value of $B$ is in the range of 0.8 to $1.9 \mathrm{mg} / \mathrm{day}$ according to the U.S. Food and Drug Administration Total Diet Studies and the United Kingdom National Food Survey (42).

\section{Al Concentrations}

The highest $\mathrm{Al}$ concentrations at $1370 \pm 37.3 \mathrm{mg} / \mathrm{kg}$ were determined 
in $H$. albus, whereas the lowest amount of $930 \pm 28 \mathrm{mg} / \mathrm{kg}$ was determined in $H$. leptocalyx. The presence of some heavy metals, including $\mathrm{Al}$ in selected medicinal plants belonging to the Lamiaceae, Guttiferae, Gentianaceae, Acanthaceae families were investigated and the $\mathrm{Al}$ concentrations were reported to be in the $1.45-4.07 \%$ range (43). Lower concentrations of $\mathrm{Al}$ at $154-412 \mathrm{mg} / \mathrm{kg}$ were determined in medicinal plants sampled from Arak, Iran (44). ICP-OES was employed to determine the $\mathrm{Al}$ concentration in medicinal plants from Morocco and the results were in the range of $1.22-7.91 \%$ (45). The FAO/WHO permissible Al level reported is $7 \mathrm{mg} / \mathrm{kg}$ body weight/ week to $1 \mathrm{mg} / \mathrm{kg}$ body weight/ week (46).

\section{CONCLUSION}

The trend to using medicinal plants for improving health has increased worldwide. Some plants are directly used for primarly health care. However, they can contain heavy metals many of which are toxic. Thus, it is very prudent to evaluate the metal concentrations of these plants. In this study, the $\mathrm{Cd}, \mathrm{Ni}, \mathrm{Cu}, \mathrm{Pb}, \mathrm{Cr}, \mathrm{Fe}, \mathrm{B}$, and $\mathrm{Al}$ concentrations in the Hyoscyamus (Solanaceae) species (Hyoscyamus reticulatus L., Hyoscyamus leptocalyx STAPF, Hyoscyamus aureus L., and Hyoscyamus albus L.) were determined. The accuracy of the method was controlled by the certified reference material NCS ZC 73014 Tea Leaves with satisfactory results. This study showed the applicability of the ashing method for quantitative digestion of heavy metals in plant samples and thus the limitations in sample amount and sensitivity are overcome. The study showed the applicability of the ashing method, followed by ICP-OES determination, for metals in medicinal plants.
The concentrations of $\mathrm{Cd}, \mathrm{Ni}$, $\mathrm{Cu}, \mathrm{Pb}, \mathrm{Cr}, \mathrm{Fe}, \mathrm{B}, \mathrm{Al}$ and others in plants are known to vary greatly depending on their concentrations in soil, the role in their metabolism and physiological pathways, the environmental conditions such as stress, temperature, etc. Concentrations of $\mathrm{Cu}$ in $\mathrm{H}$. reticulatus were found higher than in the other species, whereas the Cd concentrations were as low as the quantification limit. The $\mathrm{Pb}$ concentration was found at $21.69 \pm 1.172 \mu \mathrm{g} \mathrm{g}^{-1}$ for $H$. aureus, while it was clearly lower than in the other species. The concentrations of $\mathrm{Fe}$ and $\mathrm{Al}$ in the studied plants were found in the range of $268 \pm 19.7-$ $1278 \pm 117.0 \mu \mathrm{g} \mathrm{g}^{-1}$ for Fe and 930 $\pm 28.4-1370 \pm 37.3 \mu \mathrm{g} \mathrm{g}^{-1}$ for $\mathrm{Al}$. It is well known that $\mathrm{Fe}$ and $\mathrm{Al}$ are also found in soil at higher amounts. Thus, higher concentrations are expected in plants. This could be attributed to environmental factors and plant physiologies. There were no significant differences found in the $\mathrm{Ni}, \mathrm{Cr}$, and $\mathrm{B}$ concentrations of the studied plants. From these results, it can be concluded that $H$. aureus contained high amounts of $\mathrm{Ni}$ $\left(14.0 \pm 1.101 \mu \mathrm{g} \mathrm{g}^{-1}\right), \mathrm{Pb}$ $\left(21.69 \pm 1.172 \mu \mathrm{g} \mathrm{g}^{-1}\right)$, and $\mathrm{Cr}$ $\left(8.21 \pm 0.439 \mu \mathrm{g} \mathrm{g}^{-1}\right)$. The highest $\mathrm{Cu}$ concentration was determined in $H$. reticulatus at $530.2 \pm 7.00 \mu \mathrm{g}$ $\mathrm{g}^{-1}$. The Fe $(268 \pm 19.7-1278 \pm 117.0$ $\left.\mu \mathrm{g} \mathrm{g}^{-1}\right), \mathrm{B}\left(7.8 \pm 0.66-20.7 \pm 1.75 \mu \mathrm{g} \mathrm{g}^{-1}\right)$, and $\mathrm{Al}\left(930 \pm 28.4-1370 \pm 37.3 \mu \mathrm{g} \mathrm{g}^{-1}\right)$ concentrations agreed well with literature values.

\section{ACKNOWLEDGMENT}

The present work was carried out under the financial support of Mardin Artuklu University (MAÜ/BAP/SYO/2011/11). The authors thank Dr. Ersin KILINC from Mardin Artuklu University for his valuable contribution and comments on the manuscript.

Received February 13, 2014.

\section{REFERENCES}

1. I. Kosalec, J. Cvek and S. Tomic, Arh. Hig. Rada. Toksikol. 60, 485 (2009).

2. K.L. Soeken, S.A. Miller and E. Ernst, Rheumatology 42, 652 (2003).

3. T.P. Fan, G. Deal, H.L. Koo, D. Rees, H. Sun, S. Chen, J.H. Dou, V.G. Makarov, O.N. Pozharitskaya, A.N. Shikov, Y.S. Kim, Y.T. Huang, Y.S. Chang, W. Jia, A. Dias, V.C.W. Wong, and K. Chan, J. Ethnopharmacol. 140, 568 (2012).

4. J. Varon, Am. J. Emerg. Med. 27, 113 (2009).

5. B.C. Soner, A.S. Sahin and T.K. Sahin, Eur. J. Integr. Med. 5, 547 (2013).

6. F.U. Afifi, M. Wazaify, M. Jabr and E. Treish, Complement. Ther. Clin. Pract. 16, 208 (2010).

7. U.C. Lavania, J.S. Kushwaha, S. Lavania and S. Basu, J. Genet. 89, 493 (2010).

8. N. Hosseini, S.N. Ebrahimi, P. Salehi, B. Asghari and M. Ahmadi, J. Med. Plants Res. 5, 3552 (2011).

9. R. Li, D.W. Reed, E. Liu, J. Nowak, L.E. Pelcher, J.E. Page and P.S. Covello, Jonathan E. Page, Chem. Biol. 13, 513 (2006).

10. M. Kartal, S. Kurucu, L. Altun, T. Ceyhan, E. Sayar, S. Cevheroglu and Y. Yetkin, Turk J. Chem. 27, 565 (2003).

11. M.A. Ebrahimzadeh, S.M. Nabavi, S.F. Nabavi, B. Eslami and S. Ehsanifar, Pharmacologyonline 2, 644 (2009).

12. L. Mateus, S. Cherkaoui, P. Christen and J.L. Veuthery, Electrophoresis 20, 3402 (1999).

13. A. El-Shazly, A. Tei, L. Witte, M. El-Domiaty and M. Wink, Z. Naturforsch C. 52, 729 (1997).

14. R.E. Schultes and E.W. Smith, Hallucinogenic Plants (A Golden Guide), Golden Press- New York 1976 Western Publishing Company, Inc., page 22, (1976).

15. F.F. Motaal, S.A. El-Zayat, Y. Kosaka, M.A. El-Sayed, M.S.M. Nassar, and S.-I. Ito, Asian J. Plant Sci. 8, 526 (2009). 
16. E. Souri, G. Amin, A. DehmobedSharifabadi, A. Nazifi and $\mathrm{H}$. Farsam, Iran. J. Pharm. Res. 3, 55 (2004).

17. S. Begum, B. Saxena, M. Goyal, R. Ranjan, V.B. Joshi, Ch V. Rao, S. Krishnamurthy and M. Sahai, Fitoterapia, 81, 178 (2010).

18. M.K. Mohammad, I.M. Almasri, K. Tawaha, A. Issa, A. Al-Nadaf, M. Hudaib, H.S. AlKhatib, E. AbuGharbieh and Y. Bustanji, Pharm. Biol. 48, 1376 (2010).

19. G.O. Guler, J. Food Biochem. 36, 532 (2012).

20. A.S. Begum, Res. J. Seed Sci. 3, 210 (2010).

21. X.Z. Li, S.N. Zhang, S.M. Liu, and F. Lu, Fitoterapia 84, 273 (2013).

22. A. Tan, Turkey: Country report to the FAO international technical conference on plant genetic resource, Leipzig, Germany (1996).

23. A. Dalar, I. Konczak, J. Herb. Med. 2, 126 (2012).

24. S.A. Sargin, E. Akcicek and S. Selvi, J. Ethnopharmacol. 150, 860 (2013).

25. E. Kilinc, A. Dundar, S. Ozdemir and V. Okumus, At. Spectrosc. 34, 78 (2013).

26. E. Kilinc, F. Aydin and M.Z. Duz, At. Spectrosc. 33, 173 (2012).

27 . The essential guide to herbal safety, Elsevier, Churchill, Livingstone 11830 Westline Industrial Drive, St. Louis, MO, USA, 63146, page 111 (2005).

28. D. Durović, Z. Bulat, A. Buha and V. Matovic, E3S Web of Conferences 1, 15009 (2013).

29. J.A.T. da Silva, M. Naeem and M. Idrees, Med. Aromat. Plant Sci. Biotechnol. 6, 94 (2012).

30. Z.I. Khan, K. Ahmad, M.J.Z. Rasheed, R. Nawaz, M. Ayub, A.F. Zahoor, A. Anjum, M. Yousaf, Z.U.H. Dogar, K.U. Rahman, A. Rauf, M.K. Mukhtar, S.A.H. Naqvi, M. Shaheen, A. Fardous, S. Gondal, S. Naheed, S. Ahmad, G. Hussain, M. Sher, F. Arshad, K. G. Ali, and B. Parveen, Afr. J. Pharm. Pharmacol. 7, 1389 (2013).
31. M.A.G. Maobe, E. Gatebe, L. Gitu and $\mathrm{H}$. Rotich, Global J. Pharmacol. 6, 245 (2012).

32. D.S. Stef, I. Gergen, T.I. Trasca, M. Härmänescu, L. Stef, M. Druga, R. Biron and G. Eeghedus-Mîndru, Scientific Papers: Animal Sci. Biotechnol. 43, 127 (2010).

33. S. Shavakh, S. G. Kavkani and J. Nouri, Asian J. Chem. 25, 2977 (2013).

34. M.M.A. Campos, H. Tonuci, S.M. Silva, B.de S. Altoé, D. de Carvalho, E.A.M. Kronka, A.M.S. Pereira, B.W. Bertoni, S. de C. França and C.E.S. Miranda, Phytochem. Anal. 20, 445 (2009).

35. S.I. Korfali, M. Mroueh, M. Al-Zein and R. Salem, J. Food Res. 2, 70 (2013).

36. EFSA Panel on Food Additives and Nutrient Sources added to Food (ANS), EFSA Journal 8(12), 1882, 2010.

37. P. Konieczyński, M. Wesołowski and P. Rafalski, Herba Pol. 53, 27 (2007).

38. S.A. Khan, L. Khan, I. Hussain, K.B. Marwat and N. Akhtar, Pak. J. Weed Sci. Res. 14, 101 (2008).

39. N.K.S. Singh, C.B. Devi, T.S. Singh and N.R. Singh, Indian J. Nat. Prod. Resour. 1, 227 (2010)

40. Iron in Drinking-water, Guidelines for drinking-water quality, 2nd ed. Vol. 2. Health criteria and other supporting information. World Health Organization, Geneva, Switzerland (1996).

41. R.N. Sah and P. H. Brown, Microchem. J. 56, 285 (1997).

42. Guidelines for drinking water quality, 2nd ed. Addendum to Vol. 2. Health criteria and other supporting information. World Health Organization, Geneva, Switzerland (1998).

43. F. Inam, S.S. Deo, N.S. Kadam and R.P. Mahashabde, Res. J. Pharm. Biol. Chem. Sci. 3, 57 (2012).

44. M. Delavar, G.R. Asghari, F. Amiri and M. Abdollahi, Iran. J. Toxicol. 5, 482 (2011)

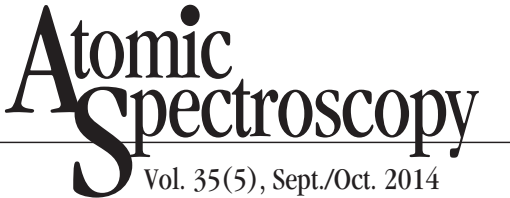

45. B. Imelouane, M. Tahri, M. Elbastrioui, F. Aouinti and A. Elbachiri, J. Mater. Environ. Sci. 2, 104 (2011).

46. T. Stahl, H. Taschan, H. Brunn, Environ. Sci. Euro. 23, 37 (2011). 